Abbreviated Key Title: Sch J Med Case Rep

ISSN 2347-9507 (Print) | ISSN 2347-6559 (Online)

Journal homepage: https://saspublishers.com

\title{
Tornwaldt Nasopharyngeal Cyst: Case Report and Review of Literature
}

Mohamed Amine Hanine*, Mohammed ELAKHIRI, Abdelfattah ALJALIL, Youssef Darouassi, Haddou AMMAR

ENT and CFS Department, Avicenne Military Hospital, FMPM Cadi Ayad University - Marrakech - Morocco

DOI: $10.36347 /$ sjmcr.2020.v08i12.006

| Received: 27.11.2020 | Accepted: 07.12.2020 | Published: 16.12.2020

*Corresponding author: Mohamed Amine Hanine

Abstract

Case Report

Tornwaldt's cyst (TC) is the presence of cystic swelling of the midline of the nasopharynx. It is a rare benign pathology which mainly interests adults. Clinically large cysts result in compressive rhinological syndrome which requires radiological exploration. We report the case of a patient with a Tornwaldt cyst to provide an update on this rare pathology.

Keywords: Tornwaldt's cyst, benign developmental cyst, Nasopharynx.

Copyright $\odot 2020$ The Author(s): This is an open-access article distributed under the terms of the Creative Commons Attribution 4.0 International License (CC BY-NC 4.0) which permits unrestricted use, distribution, and reproduction in any medium for non-commercial use provided the original author and source are credited.

\section{CASE REPORT}

This is a 56-year-old patient with no pathological history, who has presented for 6 months with progressive nasal obstruction, associated with purulent, intermittent fetid posterior rhinorhea, without earache, anosmia or epistaxis.

Endoscopic workup revealed a bulging of the posterior wall of the nasopharynx [Fig1], covered with a normal mucosa, and without obstructions in the orifice of the Tromps d'eustaches.

The CT scan of the cavum objectified the presence of a nasopharyngeal cyst occupying the posterior superior endoluminal part measuring $16 \mathrm{~mm}$ long axis.

The patient underwent endoscopic marsupialization under local anesthesia, revealing a thick yellowish content which was sterile bacteriologically studied.

The anatomopathological study of the surgical specimen did not find any signs of malignancy.

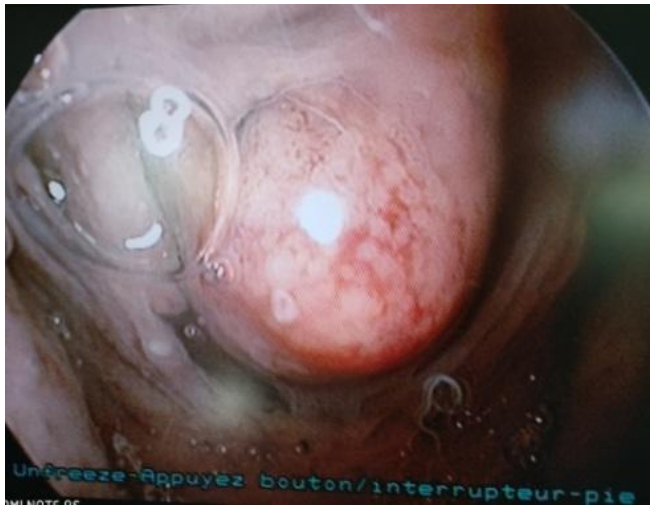

Fig-1: Nasopharyngeal endoscopic view showing a cystic mass

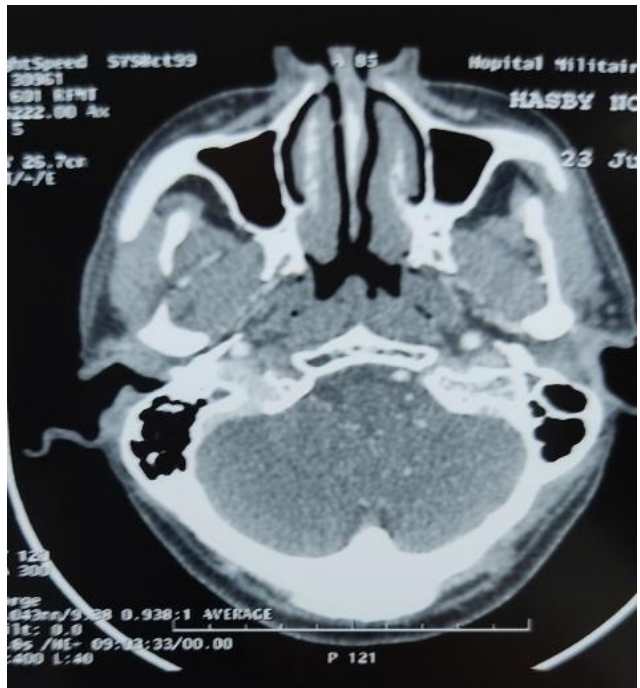

Fig-2: Plain axial CT scan showing the nasopharyngeal mass 


\section{Comment}

Tornwaldt's cyst is a malformative and congenital cyst of the nasopharynx, can also be of iatrogenic origin following surgery, nasopharynx, chemoradiation or adenoidectomy $[1,2]$.

Cystic formation develops medially at the nasopharyngeal level within the prevertebral muscles. It's first described in the literature by Dr. Gustoff L. Tornwaldt in the 19th century as one of the causes of pharyngeal discomfort [3].

The symptomatology is poor, nonspecific directly related to the size of the cyst. Usually the patient reports nasal obstruction, with posterior rheenorhea, pharyngitis, halitosis, associated with earache, occipital headache, or clinical signs related to tubal dysfunction [4].

The positive diagnosis is based on the endoscopic examination of the nasal cavities which confirms the presence of a well-limited smooth tumefaction of the postero-superior wall of the nsopharynx [Fig 1], covered with a mucous membrane of normal appearance, without ulceration or vegetation.

Radiological exploration confirms the diagnosis by the absence of signs in favor of malignancy, and by showing a well-defined low density lesion on CT scan [Fig 2].MRI remains the best, most sensitive examination to detect the cyst, assess its size, content and relationship to surrounding structures [5]. The cyst has high signal intensity on $\mathrm{T} 1$ and attenuated in $\mathrm{T} 2$, without enhancement effect by contrast to gadolinium $[6,4]$.
Therapeutic management is essentially surgical by an incision or marsupialization of the cyst. It is necessary for large lesions, symptomatic, with otological or infectious complications.

The course is marked by the disappearance of clinical signs without recurrence in the medium and long term.

\section{CONCLUSION}

It is a benign pathology discovered incidentally for lesions of small size, but the clinical signs of large cysts pose the problem of differential diagnosis with malignant pathology of the nasopharynx.

\section{REFERENCES}

1. Miyahara H, Matsunaga T. Tornwaldt's disease. Acta Oto-Laryngologica. 1994 Jan 1;114(sup517):36-9.

2. Ikushima I. MRI imaging of Tornwaldt's cysts, Am. J. Roentgenol. 1999: 1663-1665.

3. Chong VF, Fan YF, Radiology of the nasopharynx: pictorial essay, Australas. Radiol. 2000; 44: 5-13.

4. Alshuhayb Z, Alkhamis H, Aldossary M, Almoumen Z, Aldhurais A, Alshuhayb B, Almomen A. Tornwaldt nasopharyngeal cyst: Case series and literature review. International Journal of Surgery Case Reports. 2020 Sep 21.

5. Yanagisawa E, Yanagisawa K. Endoscopic view of Thornwaldt cyst of the nasopharynx. Ear, Nose \& Throat Journal. 1994 Dec;73(12):884-5.

6. Marom T, Russo E, Salem DB, Roth Y. Nasopharyngeal cysts. International journal of pediatric otorhinolaryngology. 2009 Aug 1;73(8):1063-70. 